\title{
Right to buy: A proposal to end the student loans crisis
}

\section{Estelle Clarke}

Solicitor, UK

\begin{abstract}
The UK student loans system is in crisis and the government plans to sell off student loans to corporate purchasers. Such loan sales disadvantage government, the taxpayer and student borrowers. The government should give student borrowers the 'right to buy' their own loans for the same price the government is prepared to sell those loans to corporate purchasers. If borrowers purchased their own loans, disadvantages of loan sales would transform into advantages. The 'right to buy' can fairly be extended to all borrowers, regardless of whether their loans are being sold; this is done by extending the 'right to buy' as a 'right to reduce' student loans. The 'right to reduce' also provides a solution to the problem of how to 'deal with' existing student debt. Because the 'right to buy' and the 'right to reduce' both follow government's pricing for loan sales, they should be universally acceptable; moreover, government, taxpayers and borrowers would be better off.
\end{abstract}

\section{Keywords}

Student loans, tuition fees, student finance, loan sales, student loan sales, right to buy

\section{Executive summary}

The UK's student finance system is inequitable and in crisis. Nevertheless, in February 2017 the Conservative government announced that the process to start selling more student loans to private investors had begun. Student loan sales disadvantage student borrowers, taxpayers and the economy. When the government sells student loans to private investors, it sells them for a fraction of their 'face value'.

This paper recommends that affected student borrowers be given the 'right to buy' their own loans for the same fractional price that the government is prepared to sell their loans to private investors. Giving student borrowers the 'right to buy' would transform disadvantages of loan sales into advantages for student borrowers, taxpayers and the economy while unburdening student borrowers from punitive debt.

\section{Corresponding author:}

Estelle Clarke, Hampshire, UK. Website: https://www.estelleclarke.com/

Email: estelleathalterworth@yahoo.co.uk 
The government would be no worse off. Because the 'right to buy' formula is based on loan sales proposed and priced by the government, the cost parameters must inevitably be acceptable to government. A refusal to allow student borrowers this 'right to buy' would indicate that the government prioritises corporate wealth over the nation's education.

The justice of student borrowers having the same 'right to buy' as private investors implies that if some borrowers have the 'right to buy', so should others, even if their loans are not being sold. Therefore, this paper outlines a 'right to reduce' for borrowers whose loans are not being sold. The 'right to reduce' is substantively equivalent to the 'right to buy'. Being predicated upon government's own pricing for student loan sales, the 'right to reduce' should also be universally acceptable. The addition of detailed supportive mechanisms should ensure that the less well-off have equal access to the 'right to buy' and 'right to reduce'. These solutions provide a way of reducing student borrowers' debts while student funding is returned to an equitable system and/or tuition fees are abolished.

\section{Introduction: Student loans and the history of loan sales}

Higher education in Britain used to be free. But since the 1990s, the British government has largely absolved itself from the role of prime funder of higher education with the introduction of student loans for tuition fees and maintenance. ${ }^{1}$ The greater responsibility of funding the nation's higher education has been transferred from government to students and remains with student borrowers for the duration of their loans - potentially more than thirty years after graduation. Students borrow tuition fee and maintenance loans from the government, the latter since 2016 when maintenance grants were abolished (Figure 1). Student borrowers repay the government the amount lent and interest and costs on top, until the loans are repaid or end, by being written off after 30 years of payments. Loan terms are deliberately unregulated and widely regarded as unfairly punitive; for example, students are charged an extortive $6.1 \%$ interest rate, compounded monthly. ${ }^{2}$ Financial pressure on student borrowers is significant.

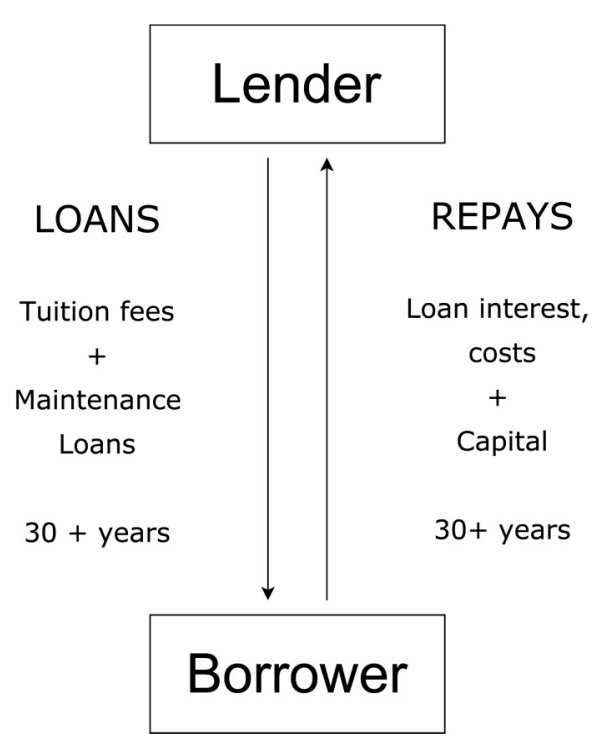

Figure 1. Lender/borrower structure of the student loans system. Source: Author's own.

Lender $=$ the government, acting through any person on its behalf (such as the Student Loans Company [SLC]); and Borrower = student borrowers, referenced as 'student borrowers' or 'borrowers' (some as school children when taking up loans). 
As more students took out loans, the government regarded the loans with a seller's eye, and in 1998 and 1999, the government began selling the student loans. In 2013, the Department for Business, Innovation and Skills (BIS) announced the sale to Erudio of "outstanding student loans owed by around a quarter of a million borrowers for $£ 160$ million" (BIS, 2013: paras. 2 and 3). This transaction highlighted the practice of the government accepting a sale price, which was only a fraction of the 'face value' of the loans; the loans Erudio purchased for $£ 160$ million had a 'face value' of around $£ 890$ million (BIS, 2013: note 6). In the 2016 Autumn Statement, the Chancellor stated that the government "is continuing to pursue the sale of the pre-2012 income contingent repayment student loan book" (HM Treasury, 2016: para. 1.65). Then, in February 2017, it announced that, "The process to start selling part of the English student loan book ... has begun" (DfE, 2017: para. 2). The government proposes to do this transaction by way of securitisation (DfE, 2017: note. 8). In crude terms, securitisation is a finance structure that pools assets and repackages them into interest-bearing securities: student loans are the assets to be pooled together and sold to a purchaser who repackages them into interest-bearing securities. These securities are then sold to investors. Investors' return originates from students' payments under their loans and any additional payments, for example from the government seller. The purchaser is often a special-purpose vehicle set up to buy the loans, repackage and sell them. The government receives the purchase price from the purchaser who pays investors using money received from student borrowers under acquired loans. The more money the purchaser gets from borrowers, the more profit it makes.

It is typical for the sale price of the loans to be calculated referencing the 'face value' of the loans. ${ }^{3}$ Erudio's payment of $£ 160$ million for student loans with a 'face value' of $£ 890 \mathrm{~m}$ was only 18\% (BIS, 2013: notes. 6 and 4). Most loans that Erudio purchased belonged to borrowers who were "not meeting their obligations under the terms of the loan agreement, or who are earning below the deferment threshold" (BIS, 2013: note 5). Given that "more than three-quarters of students can expect to have some debt written off, up from around $40 \%$ under the 2011 system" (Belfield et al., 2017: 19), the Erudio percentage figure is used herein as an example price for loan sales. In reality, the price cannot be accurately predicted: the price varies deal to deal and is dependent on the specifics of each deal. For example, the characteristics of the loan 'basket' being sold, such as the ratio of 'good' borrowers to 'bad', and negotiating strength of respective parties. Whatever the specifics of the deal are, the price paid by the seller will be a fraction of the 'face value' of the loans (the 'sale fraction'). For example, a student loan of $£ 40,000$ sold for a sale fraction of $18 \%$ would cost the loan purchaser $£ 7,200$ while a loan with a face value of $£ 55,000$ would cost $£ 9,900$.

\section{Why loan sales disadvantage student borrowers, taxpayers and the economy}

In a loan sale, the government sells its rights to be repaid the loans and receive interest and costs from the borrowers, in return for the sale fraction. Government's receipts of interest, costs and capital repayments are relinquished for 'cash up front'; regular income from borrowers' payments over the remaining loan term is exchanged for cash, which is a fraction of the value of such receipts. Once the sale is completed, the government is usually 'out of the picture' (Figure 2), so far as the borrower is concerned. The purchaser acquires rights to be repaid the loan amount and receive interest and costs from the borrowers who thereon make payments to the corporate purchaser instead of the government. Because HMRC deducts borrowers' payments from earnings at source, purchasers easily collect money from borrowers. 


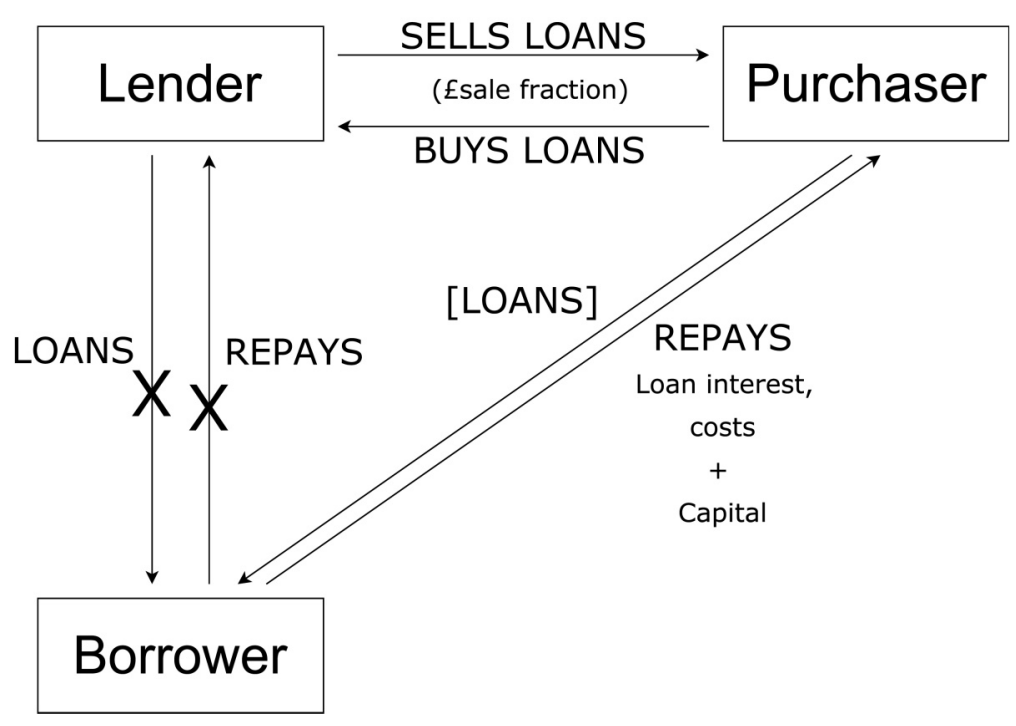

Figure 2. Lender/borrower/corporate purchaser structure of student loan sales. Source: Author's own.

Corporate purchasers legitimately regard student loans as assets to generate profit and returns for investors in the securities. But these aims conflict with the purpose of the loans, which is to educate a nation without discrimination. A corporate purchaser's incentive fundamentally conflicts with the function of the loans, and loan sales disadvantage borrowers, taxpayers and the economy, exposing them to risks.

\section{Loan sales put borrowers at risk}

Borrowers whose loans are sold are at risk of worsening loan terms, something allowed by the Sale of Student Loans Act 2008 (SSLA). They also risk problems with the loan purchaser and being unfairly 'locked in' to arrangements that do not keep up with advantageous changes arising from public and parliamentary opinion.

Enhancing the sale process of student loans for government and purchasers, the SSLA has a wealth of provisions giving government and purchasers wide powers. In contrast, the act allows student borrowers to be subject to worsening loan terms when their loans are sold, potentially passing on financial risk and burden to borrowers. For example, the SSLA allows that transfer arrangements between the Secretary of State and loan purchaser can relate not only to loans but also "some or all of the Secretary of State's rights" [Section 1(3)(b)] and include provision "For warranties or indemnities or other obligations of the Secretary of State" [Section 1(4)(c)] - these can include provisions "that the Secretary of State thinks appropriate" [Section 2(1)]. Worryingly, the Secretary of State also has power to give undertakings around and relating to making loan regulations, including "to achieve a specified result" or not "achieve a specified result". Such provisions have teeth; not only can the loan purchaser "enforce an undertaking by way of legal proceedings" [Section 2(5)(e)], but also the Secretary has power to increase costs to students and this can apply retrospectively [Section $5(4)$ and (5)]. The nail in the coffin for borrowers is that the SSLA allows borrowers to be worse off as a result of a loan sale. The act provides only that "in amending loan regulations the Secretary of State shall aim to ensure that no borrower whose loan is transferred is in a worse position" [Section 5(6)]. The use of the phrase 'aim to' is important: the Secretary need not ensure borrowers are no worse off because of a loan sale; nor must the Secretary endeavour 
or make reasonable efforts to protect borrowers. There is not even a requirement of reasonableness for the Secretary's actions under the SSLA. The Secretary need only 'aim to' ensure borrowers are no worse off. This offers no effective protection for borrowers because the Secretary could worsen borrowers' positions while aiming not to.

In allowing regulations to be changed, the SSLA puts student borrowers in an invidious position: adverse retrospective changes to loan terms could be imposed on them. Hammering home borrowers' vulnerability to corporate desire in the event of a loan sale, the SSLA allows: "A reference in loan regulations to the Secretary of State as lender includes a reference to a loan purchaser" [Section 5(1)]. Were student loans regulated this would not be allowed, but the SSLA removed student loans from protective legislation including by Section 8.

In summary, the SSLA allows loan purchasers wide powers on a loan sale, including the procurement of borrower-adverse and retrospective changes to loan terms. Loan sales risk purchasers' using and abusing the SSLA to elevate entitlement and demand from students and government to return more profit; for example, by securing changes to loan terms which increase receipt of the punitive compounding interest accruing on the student loans and/or capital repayment. However right or wrong such an action might be, purchasers could take the borrowers' money first via deduction at source through HMRC and argue about it later. It is concerning that to increase receipts under bought loans, a purchaser might seek to change loan terms by increasing the repayment rate of $9 \%$ (of income over the threshold); lowering the threshold for repayment (presently £21,000 and from April 2018, £25,000 for those who started university after 2012); extracting additional payments under the loans via a higher rate of repayment; and/or demanding that a portion of any lump sum receipts (such as inheritance and/or capital gains) go towards loan repayment. The risk of a borrower suffering in a corporate loan sale is heightened because the government has a track record of retrospectively changing the terms of student loans and has not given borrowers a binding commitment to protect them.

Problems with loan purchasers resulted in previous loan sales not running smoothly. The "catalogue of problems" (Media FHE, 2013: para. 9) reported after Erudio took over its loan book included: difficulty deferring loans; a change of policy regarding information being registered with credit reference agencies; payments being taken by mistake; failing to send deferral forms and then demanding early payments; and risking borrowers' ability to get mortgages or borrow for big purchases later in life (Erudio wrote "to around 45,000 people who deferred repayments to say their details would be given to credit reference agencies" [Lunn, 2014]). One forum, moneysavingexpert.com "runs to 259 pages of complaints" (Lunn, 2016) and Lewis (2014: para. 3) wrote that the forum "is rammed with former students who are struggling with Erudio".

\section{The student loan system and mental health}

Student loans can contribute to mental ill health. ${ }^{4}$ Students graduating with the largest loans tend to be the less well off, especially since maintenance grants were replaced with loans, forcing the less well off into twice as much debt as their better off peers. This institutionalised discrimination against the less well off makes education inequitable and uneven in its accessibility. Callender and Jackson (2005: 15) report a bitter irony: "Students from poorer backgrounds are more debt averse than those from other social classes", yet they expect to graduate with roughly double the debt and costs of those from better-off families $(£ 60,000$ for a three-year course because they have maintenance loans as well as tuition loans). It is a 
corollary that mental ill health of affected borrowers will be accentuated by loan sales which place loans in a profit driven culture. For example, borrowers of sold loans are at risk of adverse changes imposed by or for the purchaser. Further, such borrowers have their loan terms 'crystallised' on the sale and a corporate purchaser will be reluctant to accept loan changes which reduce profits from acquired loans (unless the purchaser is 'compensated'). Borrower-friendly changes to unsold loans are expected but borrowers of sold loans are 'locked in' to loan terms and risk not benefiting from such changes. Borrowers whose loans are sold risk a 'double whammy' of purchaser driven adverse changes and crystallised loan terms. Such borrowers are therefore at higher risk of mental ill health and stress.

Coinciding with increasing financial pressure on students from higher tuition fees and maintenance loans, more students are dropping out of university including because of mental health problems. In 2016, 36\% of students said they "worry about their finances to such an extent that [it] is affecting their mental health" (Future Finance, 2016: para. 1). Additionally, in 2017 , " $75 \%$ of students polled who receive a maintenance loan feel stressed about the amount of debt they are accumulating while studying, the effects of which are wide reaching" (Intelligent Environments, 2017: para. 3). When monthly loan payments negatively impact borrowers' ability to pay their bills, this stresses borrowers (Andrews, 2004: 510, 511). Because a loan sale 'crystallises' loan terms, borrowers are 'locked in' to a debt-dictated life. Cruelly, debt-averse borrowers can be subject to prolonged debt and lasting difficulty making ends meet, which impacts mental ill health.

Borrowers' mental ill health risks associated with student loans is exacerbated by debt not being 'meaningful'. There may be some 'meaning' in tuition fee debt used to actually pay for tuition fees, but arbitrary interest compounded monthly incrementally increases the size and costs of student loans, making them last longer (Clarke, 2017) and creating an extra portion of 'compounded' debt which is not used to pay tuition fees but benefits the loan purchaser and investors. In February 2017, the Department for Education admitted, "Ioans which are being sold have already been in repayment for over 10 years, and much of the original value of the loans has already been paid back to government" (DfE, 2017: note 5). The extra and enlarging 'compounded' loan portion cannot reasonably have meaning for borrowers and will therefore be more stressful and associated with greater mental ill health and societal costs. Ultimately, these costs fall upon the taxpayer. It may be too early for research to unequivocally quantify the damage to borrowers' mental health because of loan sales, but that does not detract from the reality of it for those suffering.

\section{Parliamentary opinion is turning against student loans}

Reflecting the public's growing dissatisfaction with the student loan system, parliament has now also begun to criticise the system. The collective power of public and parliamentary opinion is likely to force borrower friendly changes to alleviate the crisis, but borrowers whose loans are sold risk being unfairly 'locked in' to unregulated and unfair loans and unable to benefit from borrower-friendly changes to loan terms, while borrowers of unsold loans benefit from positive changes.

Before the 2017 general election, parliamentary criticism of the system was growing. The House of Lords made its views clear on 5 April 2017, passing a Motion to Regret: "retrospectively changed loan conditions for existing students are further incremental burdens on students that risk worsening the opportunities for young people from low-income backgrounds" (House of Lords, 2017: Columns 1102, 1116-18). The understanding that 
student loans are a debt trap was widening, and was even shared by a Conservative party MP who used such terminology emailing a constituent ("I understand you to be saying that you have to earn $£ 41 \mathrm{k}$ just to 'chip away' at the underlying debt figure, because of compounding [interest]. I am looking into this. If that were correct, I agree that this could create a debt trap"). The political landscape for student finance was changed by Labour's general election manifesto promise to abolish tuition fees and return maintenance grants. The Liberal Democrat, Green and UKIP manifestos also addressed the finance system. Labour's position won younger votes and eroded the Conservative majority. Henceforth, no party can afford to ignore student finance if it wishes to command power.

Not only did the election result ignite interest in changing the system, it also amplified political voices. On 1 July 2017, Conservative minister Damian Green said of students facing big debts: "I think this is clearly a huge issue ... It may well be that this is a national debate that we need to have" (Grierson, 2017: para. 8). Lord Adonis, a former education minister, challenged the student finance system, accusing universities of running a tuition fees cartel and asking the Competition and Markets Authority to investigate (Woolcock, 2017: paras. 1 and 2). He broadened debate around the finance system on 28 June 2017, writing in The Times, "Tuition fees are being killed off by university greed ... VCs need to start planning for real austerity. The flow of money from $£ 9,000$ fees will soon dry up" (Adonis, 2017). On 17 August, a former Chief of Staff, Nick Timothy, wrote in The Telegraph that tuition fees are a "pointless Ponzi scheme" which are "blighting young people's futures" and must be "radically reformed" (Timothy, 2017). The DUP neither share nor are required to support the Conservative approach to student finance. Political will and ability to improve the student finance system was illustrated by the passage of a Labour motion in the House of Commons blocking a rise in tuition fees, on 13 September 2017.

Simultaneously, the tide seems to have turned against austerity and aversion to tackling poverty. Given that the student finance system and the sale of student loans to corporate purchasers discriminates against the less well off (including because they have larger loans and are worse affected), loan sales to the private sector could be something the House of Commons will not support, once aware of the consequences of such transactions - and awareness is growing. The July 2017 Institute of Fiscal Studies' (IFS) report spells out: "students from the poorest $40 \%$ of families graduating with the largest debts ... Due to their higher principal debt, students from poorer households accrue the most interest during study; students from the poorest $40 \%$ of families now accrue around $£ 6,500$ in interest during study" (Belfield et al., 2017: 18). The student finance system discriminates against poverty because the poorer pay more than their better off peers for the same education.

Together, public knowledge and parliamentary opinion are powerful. Their simultaneous force can reasonably be expected to exert transformative influence, improving student finance. But borrowers whose loan terms are 'crystallised' by a loan sale may not benefit from such changes, or not without difficulty. Such borrowers can experience on-going and far-reaching negative consequences by, for example, being chained to expensive monthly payments. This constrains their ability to own a home, ${ }^{5}$ because the Financial Conduct Authority's 'responsible lending' rules require mortgage offers to be based on affordability. Loan payments mean that student borrowers qualify for smaller mortgages, while deductions from earnings for loan payments inhibit saving for a deposit.

As well as adversely affecting student borrowers, student loan sales disadvantage taxpayers and the economy. By selling off the loan book and losing its right to a 30-year [plus/less] flow of repayments, the government sacrifices taxpayer income for cash upfront that is a fraction of the value of the loans. As the IFS reported, "selling the loan book for its 
expected value does not 'improve' government finances” (Belfield et al., 2017: 35). Andrew McGettigan (2015: para. 17) writes:

The IFS dismissed Osborne's claim that you can finance new loans by selling old ones as 'economic nonsense'. You cannot sell an asset for what it is worth to strengthen public finances. You can only change the timings: cash today or cash spread over thirty years and more.

Moreover, in July 2017 the IFS reported that "the long-run taxpayer cost of HE finance [Higher Education finance] is now heavily contingent on the repayment of these loans" (Belfield at al., 2017: 7). It seems irrational for the government to sell loans when it needs to receive longterm repayment from them; especially when changes have been made to "the accounting of the current value of student debt" to value future payments more highly (Belfield et al., 2017: 8). The government is essentially selling off cheap something that it needs and treats as being of high value. As McGettigan (2017: 16) puts it:

A sale will likely make significant losses for government... the government may improve the headline public finance statistics ... but its misplaced valuation of cash today over holding the loan assets will lead at best to a presentational gain, not a fiscal or economic one.

\section{Calculating the true social costs of student loans}

In HM Treasury Guidance, Lowe (2008: 7) states that when determining value for money in assessing assets for disposal, public bodies should include "social cost-benefits of retention". Dwarfing the cost of student debt, which totalled $£ 100.5$ billion in March 2017 including compounded interest (Britton et al., 2017: para. 5), annual mental ill health cost in England in 2016 was estimated to be $£ 105$ billion (MHT, 2016: 10). A portion of this mental ill health cost is attributable to loan sales and should be assessed as a 'social cost' when assessing loans for disposal.

Larger student loans with punitive terms saddle the debt averse less well off with more debt and the likelihood of effecting worse mental ill health, associated costs of which include treatment and lack of earnings - and relevant to those costs is the loan duration, which can be more than thirty years. Such costs are reasonably expected to be more in relation to sold loans, leading to mounting pressure on borrowers including from 'crystallising' terms and increasing negative impact on borrowers. In 2014, when the OECD said that the "UK needs to tackle the high cost of mental ill health", it then cost the UK "around $£ 70$ billion every year, or roughly $4.5 \%$ of GDP, in lost productivity at work, benefit payments and health care expenditure" (Singh, 2014: para. 1). Mental ill health costs have increased contemporaneously with student funding increasing its burden on borrowers through bigger loans and harsher borrowing terms. Selling student loans will add to that cost where sold debts are more stressful for student borrowers. If only 18,000 borrowers a year end up on disability benefit and/or unable to work every year because of pressures from their sold student debt, ${ }^{6}$ this could add anywhere upward from $£ 594$ million per annum to the mental health care bill, ${ }^{7}$ totalling nearly $£ 20$ billion by 2050 . To give this figure some context, the IFS reports that in 2050, a policy of "writing off the post-2012 English tuition fee loans would "increase the debt by around $1 \%$ of national income by 2050 ; equivalent to around $£ 20$ billion in today's terms" (Britton et al., 2017: para. 8).

Loan sales have more 'social costs': they add to deterrents causing falling admissions and skills shortages in, for example, nursing and areas of economic growth such as film. If 
social cost-benefits were correctly factored into student loan sales, HM Treasury's 'value for money' test would not be satisfied for proposed loan sales. However, ensuring the test is properly applied is difficult: the SSLA [Section 4(3)] only requires that a report on the loan sale be laid before parliament "during the period of 3 months" from the date of agreement.

\section{Taxpayer and fiscal risk}

The taxpayer is also exposed to financial risk of an agreement to subsidise and/or compensate Ioan purchasers since Clause 2(4) of the SSLA allows the Secretary of State to "pay compensation to the loan purchaser".

In the late 1990s ... two f1billion tranches of 'mortgage-style' loans were sold to third parties ... the government committed to paying an annual subsidy to the purchaser. These subsidies were expected to exceed the costs of keeping the loans on the government's balance sheet by roughly $£ 140$ million. (McGettigan, 2013: 178, emphasis added)

This cost was later revised to $£ 125$ million. Compounding interest charged to student loans elevates purchasers' expectations of receipts and a compensation payment may well be correspondingly elevated, putting the taxpayer at more risk. Thus, loan sales expose the taxpayer to unnecessary financial risk created by the government overcharging students. The public purse also risks poor ratings on the securities issued pursuant to the sale, since student loans do not conform to regulations. If the securities are rated poorly, their pricing and saleability may worsen. This could mean that the securities are only attractive to purchasers if they are 'supported' by government promises of 'compensation'. Such 'compensation' will ultimately come out of taxpayers' pockets.

In addition, loan sales risk spending. The economy needs consumer spending and "slower consumer spending growth" is predicted in the near future (PWC, 2017: 3). Student borrowers have less spending when making expensive and extended loan payments. Sold loans maintain and/or raise overall levels of indebtedness while interest payments and loan repayments end up in the bank accounts of the "favoured few" purchasers, instead of oiling the economy as consumer spending (Harari, 2017: 17). Moreover, government loses flexibility in managing sold loans and cash receipts in the economy, thus putting the economy and taxpayer at risk. A few get richer while taxpayers have an economy starved of consumer spending diverted away from the taxpayer and into investors' pockets. Student loan sales can contribute to household debt entrenched at levels too onerous to repay. The government's aim to secure the economic well being of the country cannot be properly fulfilled via loan sales to corporate purchasers.

\section{How a student 'right to buy' would work for the less well off}

Notwithstanding the problems and risks associated with student loan sales, such deals remain 'on the table'. It would be prudent for the government to consider other ready buyers. It seems obvious that any sensible government should offer student borrowers the same 'right to buy' their own loans as it offers private purchasers; not least because the government would receive the same purchase price but such sales will not require 'compensation' payments. If student borrowers were offered and exercised the 'right to buy' their own loans from the government (Figure 3), they would pay the government the sale fraction for their loans. Having purchased their own loans, such borrowers would not have to pay a single penny more in loan 
repayments, interest or costs. They would have rid themselves of their loans for a fraction of their 'face value'. Just as SLC handles loan repayments now, it could manage the mechanics of borrowers' loan purchases, liaising between borrowers and HMRC for the deduction of the purchase price from borrowers' earnings. Administration costs of selling to borrowers may be the same, or less, than selling to a corporate purchaser because the administration structure for sales to borrowers is in place.

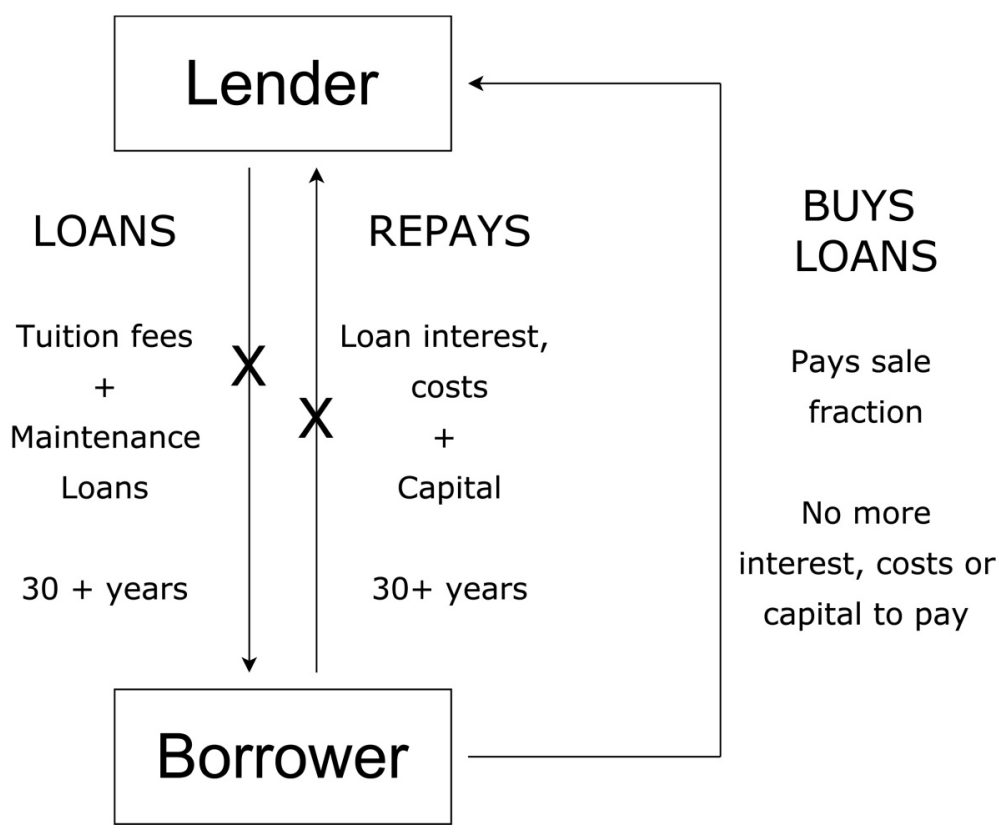

Figure 3. Lender/student borrower purchase structure for student loan sales. Source: Author's own.

It is imperative that the 'right to buy' student loans is equally available to less well off borrowers; otherwise, they would be left with increasing student debts while the better off improve their lives, debt free. Support is suggested whereby less well off borrowers buy their loans using money from funds that advance them the loan purchase price. Advances would be means-tested and interest free with a fair and affordable repayment schedule deducting from earnings by HMRC and ensuring that the less well off do not pay more. The SLC is placed to administer this and process payments, ensuring that advanced funds are applied to pay the purchase price.

There are various fund options. One is to implement a variation of the existing $£ 100$ million 'Rutherford Fund' model announced by the government on 4 July 2017 to attract researchers to the UK. Another is a new industry fund established with obligatory and taxdeductible contributions or levy from [categories of] industry making most money from graduates. There could be a new universities/further education 'right to buy' fund with contributions from educational establishments - calculated by referencing student numbers, turnover and/or profit, or following a formula such as adopted by the National Scholarship Programme - whereby universities matched government funds into the Programme to support less well off students at university (Dearden and Jin, 2014). Alternatively, there is an even more straightforward method of implementing a fair 'right to buy' option for the less well off: once the right is exercised, relevant borrowers' indebtedness with the SLC is reduced to the purchase price and a fair means-tested repayment schedule (interest free) of that price agreed and implemented. This would be administratively efficient because the SLC manages student loans and HMRC deducts repayments at source. HMRC would continue to take deductions only 
until the purchase price was paid in full. Or, a 'melded approach' could be adopted with more than one fund involved and/or borrowers' own funds being 'topped up' where appropriate. Again, SLC would be the administrator. Whichever approach is adopted, ensuring borrowers equal means to buy their loans reduces the risk of fewer less well off students buying their loans. This would also maintain consistency in loan pricing because 'poor risk' loans would not dominate the asset 'basket'.

\section{How the 'right to buy' benefits student borrowers, taxpayers and the economy}

In a loan sale to borrowers, disadvantages of loan sales to corporate purchasers become advantages: borrowers' lives would not be dogged by monthly interest, costs and capital repayments via prolonged reductions to their earnings; nor would they be 'locked in' to the risk of increasing payments and disruption to terms of unregulated loans or significant restrictions in raising a mortgage. Borrowers would have more spending power, improving their individual lifestyles and those of their families; they would not endure mental ill health associated with sold student debt. The human impact cannot be overstated. There would be advantages for taxpayers, too. Taxpayers' income would not be subject to additional calls from the government to refill its coffers because having sold the loans, the government has lost a source of income and must pay 'compensation' to the purchaser; the economy would benefit from increased spending by graduates with more disposable income; and the taxpayer would benefit from an economy enjoying increased tax receipts due to less mental ill health loss of work and lower mental ill health treatment costs associated with loans sold to corporate purchasers.

\section{Extending the 'right to buy' with a substantively equivalent 'right to reduce'}

Prior loan sales have proved the government's acceptance of a fractional return on student loans. Principles of fairness and equal treatment underpin borrowers' 'right to buy' their loans for the same sale fraction the government is willing to sell their loans to private investors. The government should treat student borrowers equally and sell their loans to them for that same price; it should not discriminate against student borrowers whose loans are not sold - the 'right to buy' should be available for all borrowers.

The 'right to buy' can be made available to all student borrowers without the commercial exigency of a loan sale scenario. Existing student debt can be 'dealt with' by adopting the 'right to buy' formula for other loans on a 'matching price' basis: borrowers whose loans are not being sold have their loans recalculated in accordance with a 'right to buy' formula and process, and with its supportive mechanisms. All borrowers could therefore purchase their own loans as described, or have their loan indebtedness with the SLC reduced to the sale fraction equivalent and agree a repayment schedule which is implemented in conjunction with HMRC (continuing to) deduct repayments at source until full repayment or loan write-off (if necessary), after 30 years. This formula is, essentially, the 'right to buy' replicated as a 'right to reduce' and maintaining the use of pricing parameters known to be acceptable to government because it is what government sold and/or is prepared to sell the loans for. The "right to reduce' fulfils the imperative that all student borrowers have equal opportunity to rid themselves of student debt for their and the nation's benefit.

It needs to be noted that there are two categories of student loans: Plan One (P1) and Plan Two (P2). Some P1 loans have been sold and P2 loans have not been sold. P1 loans are pre-1 September 2012 and P2, 1 September 2012 onwards. P1 loans are smaller and cheaper than P2 loans. When P2 loans were introduced, tuition fees rose to $£ 9,000$ and the 
interest costs and charges rose; student loans started today are P2 - tuition fees are higher and maintenance loans replace maintenance grants. Because P2 loans are bigger and charge higher interest than P1 loans, without adjustments a borrower with a P2 loan would have to pay more to buy their loan than an equivalent borrower of a P1 loan, because being large and expensive bolsters P2 loan values and therefore the sales fraction is bigger: one fifth of a P2 loan would be higher than one fifth of an equivalent P1 loan.

When implementing the 'right to buy' and 'right to reduce', adjustment is needed to minimise the inequality of pricing borrowers' 'right to buy' and/or 'right to reduce' as between P1 and P2 loans. For example, the sale fraction for P2 loans should be calculated excluding maintenance loans, which should be written off. Calculations of principal and interest owed under all loans should exclude value attributed to monthly compounded interest, which distorts principal values (this distortion is worse in P2 loans because their interest rates are higher than P1 loans). The impact of monthly compound interest should be removed from borrowers' indebtedness. Finally, all payments made by the borrower (including compounded interest) should be taken into account, reducing borrower indebtedness appropriately. The sale fraction is therefore calculated as a fraction of the loans excluding maintenance loans and monthly compounded interest.

A calculation adjusted in this way makes the sale fraction as between P1 and P2 loans fairer - whether borrowers have the 'right to buy' or 'right to reduce'. It is not perfect including because the levels of tuition fees under P2 loans are higher than under P1. Further adjustment could take this difference into account. The removal of monthly compounded interest from calculations would reduce the debt burden of student loans and the sale fraction. If calculations demonstrate borrower overpayment, this can be refunded via tax credits, to increase spending in and minimise cash drain from the economy. HMRC has the structure in place to administer tax credits because it deducts loan payments at source.

The 'right to buy' and 'right to reduce' formula resolve the present student finance conundrum: the political pendulum of tuition fees is swinging and yet to come to rest. On one hand, the Conservative Party favour student loan funded higher education and student loan sales, but recognise a 'national debate' about tuition fees is needed. Conservatives need the student vote; transforming student finance to make university access equal and fair by implementing a nationwide 'right to buy' and/or 'right to reduce' loan programme would assist. On the other hand, the Labour Party says it will abolish tuition fees and reinstate maintenance grants. Jeremy Corbyn said: "I don't see why those that had the historical misfortune to be at university during the $£ 9,000$ period should be burdened excessively compared to those that went before or those that come after. I will deal with it" (quoted in Trendell, 2017). Labour needs to address existing loans if tuition fees are abolished: these could be 'dealt with' by adopting the 'right to buy' and 'right to reduce' formulae which, consistent with Labour policy, reinstate maintenance grants. A 'right to reduce' is an innovative and fair way of 'dealing with' present student loan debts while bringing the student finance system out of crisis.

\section{Conclusion}

The government's desire to sell unregulated student loans to the private sector raises big questions: Why does the government 'game the system' of funding university education, playing for cash up front by selling loans even when much of their original value has already been repaid? Why does the government demand so much money from students when it is happy to receive only a fraction of this amount back from private investors? At the very least, education should not be charged to students at more than this fraction amount. Why sacrifice 
students, taxpayers and the economy for loan sales that "make significant losses for government" (McGettigan, 2017: 16)? Is it proper governance to expose taxpayers to the risks of selling student loans? And, having removed student loans from regulatory protection, is the sale of student loans cynical exploitation of students? Such questions reflect the complexity of student loan sales: they impact the finances of government, universities, taxpayers and borrowers.

But these transactions are not just about money and statistics. Behind every loan stands a person better educating him or herself to improve their life and benefit society. Selling student loans to the private sector conflicts with the function of student finance to educate a nation. The only winners are a 'favoured few' corporate entities seeking to extract as much profit as they can from borrowers. The sale of student loans disadvantages borrowers, taxpayers and the economy. Borrowers have no protection: their loans are unregulated and legislation does not defend them. As well as prolonging borrowers' deductions from earnings for servicing expensive loans, history demonstrates that borrowers could be harassed following a loan sale and subject to adverse changes to loan terms, including when improvements to unsold loans are made for populist and/or political reasons. The mental ill health cost of locking borrowers into a loan sale is human as well as financial; it may be difficult to quantify with accuracy now, but that does not diminish its gravity or amount. In a loan sale to corporate purchasers, taxpayers are exposed to the risk of paying 'compensation' while loan income, tax receipts and spending lessen and the nation's mental ill health bill increases. If borrowers had the 'right to buy' their own loans, disadvantages of loan sales would become advantages: student loans would disappear from borrowers' lives. Borrowers would have more disposable spending and tax receipts would increase, feeding the economy and improving borrowers and taxpayers' lives while the mental ill health bill from student loans lessened. Our nation would be educated fairly and have the benefit of graduate wealth. The economy, taxpayers and students would be better off.

Public and political opinion and economic sense are changing the student loan system. The inevitable transitioning of the present system into a new, fair one can be supported by implementing a 'right to buy' and/or 'right to reduce' loan programme to 'deal with' all existing student debt. Being based on pricing used in loan sales and which is therefore within government's acceptable cost parameters, the 'right to buy' and/or 'right to reduce' should be agreeable to all parties. At the very least, the 'right to buy' and/or 'right to reduce' provides a starting point to return the student financing system to a state where students, graduates, taxpayers and the government's needs are put before the exploitation of education for investors' wealth.

\section{Notes}

1. Anderson (2016: 2): "Between 1962 and the 1990s higher education in Britain was effectively free, as the state paid students' tuition fees and also offered maintenance grants to many. In 1998 university fees were reintroduced at $£ 1,000$ per year. In 2004 they were raised to $£ 3,000$, now converted into loans repayable on an income-contingent basis, but still regarded as 'top-up' fees supplementing the state's direct grants to universities. Following the 2010 election, the basis of university finance was radically transformed as student fees, now raised to $£ 9,000$, largely replaced the teaching element in the state grants". In September 2016 maintenance grants were abolished and replaced with maintenance loans, and in April 2017, further increases to tuition fees were announced with the size of tuition fee loans increasing correspondingly. 
2. At the time of writing, "from 6 April after leaving the course until the loan is repaid in full, there is a variable rate dependent upon income. RPI (3.1\%) where income is $£ 21,000$ or less, rising on a sliding scale up to RPI $+3 \%$ (6.1\%) where income is $£ 41,000$ or more" (SLC, n.d.: para. 2).

3. Note that the 'face value' of the loans is to be differentiated from the fair value. "The BIS annual financial statements track impairments as they accumulate and are unwound. They convert the face value of BIS's asset into a fair value based on estimated future repayments. At the end of March 2014, the face value of outstanding student loans was $£ 54$ billion but the fair value (the net present value of future repayments) was estimated at $£ 33.3$ billion" (McGettigan, 2015: 28).

4. The Royal College of Psychiatrists states "Being in debt can make you feel ... Hopeless, especially if your debt is getting worse" (Dean, n.d.: 13). The Sutton Trust reports "58\% [of 16-18 year olds] say that they are concerned about having to repay student loans after their studies have finished" (Sutton Trust, 2015: para. 4). Richardson (2017: 1) reports that amongst undergraduate students, "Greater financial difficulties predicted greater depression and stress cross-sectionally, and also predicted poorer anxiety, global mental health and alcohol dependence over time ... Financial difficulties appear to lead to poor mental health in students with the possibility of a vicious cycle occurring", concluding "students financial variables appear to lead to poor mental health rather than mental health problems leading to a deteriorating financial situation. However, there appears to be a bi-directional relationship between financial difficulties and global mental health and alcohol dependence, with finances worsening mental health and vice versa suggesting a vicious cycle developing" (Richardson, 2017: final para.). Ganni (2016: para. 1) reports how "Stephen Buckley, from Mind, said tuition fee and student loan debt were major contributors to the rise in students seeking mental health help". Student loans can become "problem debt", which has "a profound impact on people's well-being, with knock on consequences for their mental health, their family life and their ability to work" (de Santos, 2014: 3).

5. In April 2014, the Financial Conduct Authority introduced 'responsible lending rules' following the Mortgage Market Review (MMR). A spokesman for the Building Societies Association said: "Under the new MMR rules, student loans are certainly considered to be committed expenditure and will be included as part of the affordability assessment" (quoted in Boyce, 2014: para. 11). The 'affordability assessment' is part of the FCA's requirement for 'responsible lending'.

6. An estimate calculated by rounding down $2 \%$ of the 984,600 students who graduate with the largest debts (tuition fees and maintenance loans): In 2015/16 the total number of students was 2,280,030 (HESA, n.d.: diagram 1, hover over relevant point); "41\% of post-2012 students received a full grant, 14\% a partial one, and 45\% no grant" (Bolton, 2017: 7); "984,600 students borrowed $£ 3.94$ billion in Maintenance Loans in academic year 2015/16, an increase of $5 \%$ from the amount paid at the same point in 2014/15" (SLC and DfE, 2016: 1, keypoint 4).

7. Allowing $£ 33,000$ per person, calculated by adding $£ 18,000$ lost productivity at work and $£ 15,000$ in benefit payments, healthcare expenditure, and so on. This does not include the human cost, such as loss of wellness and living life as an earner and provider.

\section{Legislation}

Sale of Student Loans Act 2008 (SSLA) Legislation.gov.uk [Online]. Available at: <http://www.legislation.gov.uk/ukpga/2008/10/contents>. Accessed 21 October 2017. 


\section{References}

Adonis, A. (2017) Tuition fees are being killed off by university greed. The Times [Online], 28 June. Available at: <https://www.thetimes.co.uk/article/tuition-fees-are-being-killed-off-by-universitygreed-6vngj5m5w>. Accessed 14 September 2017.

Anderson, R. (2016) University fees in historical perspective. History and Policy [Online], 8 February. Available at: <http://www.historyandpolicy.org/policy-papers/papers/university-fees-in-historicalperspective>. Accessed 26 July 2017.

Andrews, B. and Wilding, J. (2004) The relation of depression and anxiety to life-stress and achievement in students. British Journal of Psychology, 95(4): 509-21.

Belfield, C., Britton J., Dearden, L. and van der Erve, L. (2017) Higher Education Funding in England: Past, Present and Options for the Future. London: Institute for Fiscal Studies. Available at: <https://www.ifs.org.uk/uploads/publications/bns/BN211.pdf>. Accessed 27 July 2017.

BIS and The Shareholder Executive (2013) Sale of mortgage style student loan book completed. GOV.UK [Online], 25 November. Available at: <https://www.gov.uk/government/news/sale-ofmortgage-style-student-loan-book-completed>. Accessed 27 July 2017.

Bolton, P. (2017) Briefing paper: The value of student maintenance support. House of Commons Library [Online], 28 June. Available at:

<http://researchbriefings.files.parliament.uk/documents/SN00916/SN00916.pdf>. Accessed 24 October 2017.

Boyce, L. (2014) Student loan debt IS now considered when applying for a mortgage, throwing graduates' home ownership plans into jeopardy. This is Money [Online], 2 June. Available at: <http://www.thisismoney.co.uk/money/mortgageshome/article-2646007/Student-loan-debt-ISconsidered-applying-mortgage.html>. Accessed 24 October 2017.

Britton, J., Emmerson, C., van der Erve, L. (2017) How much would it really cost to write off student debt? Institute of Fiscal Studies: Observations [Online], 14 September. Available at: <https://www.ifs.org.uk/publications/9738>. Accessed 17 September 2017.

Callender, C. and Jackson, J. (2005) Does the fear of debt deter students from higher education? Journal of Social Policy, 34(4): 509-40.

Clarke, E. (2017) Packhorse Generation: The Long Debt Tail Of Student Loans. London: Intergenerational Foundation. Available at: <http://www.if.org.uk/wpcontent/uploads/2017/01/Packhorse-Generation-Report_Final.pdf>. Accessed 27 July 2017.

Dean, S. (n.d.) Debt and mental health. Royal College of Psychiatrists [Online] Available at: <http://www.rcpsych.ac.uk/healthadvice/problemsdisorders/debtandmentalhealth.aspx>. Accessed 12 September 2017.

Dearden, L. and Jin, W. (2014) The rise and demise of the National Scholarship Programme: Implications for university students. Institute of Fiscal Studies: Observations [Online], 22 October. Available at: <https://www.ifs.org.uk/publications/7410>. Accessed 8 Aug 2017.

de Santos, R. (2014) Life on The Edge: Towards More Resilient Family Finances. Step Change Debt Charity [Online]. Available at: <https://www.stepchange.org/Portals/O/StepChangeLifeontheEdgereport.pdf>. Accessed 12 September 2017.

DfE (Department for Education) (2017) Government launches first sale from the student loan book. GOV.UK [Online], 6 February. Available at: <https://www.gov.uk/government/news/governmentlaunches-first-sale-from-the-student-loan-book>. Accessed 11 September 2017.

Future Finance (2016) NUS insight: Financial woes affecting mental health. Future Finance [Online], 5 May. Available at: <https://www.futurefinance.com/uk/blog/nus-insight-over-a-third-of-studentssay-financial-woes-affecting-mental-health/>. Accessed 12 September 2017. 
Ganni, A. (2016) Tuition fees 'have led to surge in students seeking counselling'. The Guardian [Online], 13 March. Available at: <https://www.theguardian.com/education/2016/mar/13/tuition-feeshave-led-to-surge-in-students-seeking-counselling>. Accessed 21 October 2017.

Grierson, J. (2017) Damian Green admits Tories may need to review tuition fees. The Guardian [Online], 1 July. Available at: <https://www.theguardian.com/politics/2017/jul/01/damian-green-toriesmust-modernise-to-win-over-young-voters>. Accessed 17 October 2017.

Harari, D. (2017) Household debt: Statistics and impact on economy. House of Commons Library Briefing Paper No 7584, 12 June. Available at: <http://researchbriefings. parliament.uk/ResearchBriefing/Summary/CBP-7584 - fullreport>. Accessed 8 Aug 2017.

Higher Education Statistics Authority (HESA) (n.d.) Students and graduates [Online]. Available at: <https://www.hesa.ac.uk/data-and-analysis/students>. Accessed 28 July 2017.

House of Lords Hansard (House of Lords) (2017) Higher Education: Loans. Parliament UK [Online], 5 April. Available at: <https://hansard.parliament.uk/Lords/2017-04-05/debates/33D1AEB5-76454696-86E1-E6C5EED37E43/HigherEducationLoans>. Accessed 17 October 2017.

HM Treasury (2016) Autumn Statement. Available at: <https://www.gov.uk/government/uploads/system/uploads/attachment_data/file/571559/autu mn_statement_2016_web.pdf>. Accessed 27 July 2017.

Intelligent Environments (2017) Students struggling under debt-stress while at university. Intelligent Environments [Online], 20 February. Available at: <https://www.intelligentenvironments.com/students-struggling-debt-stress-university/>. Accessed 12 September 2017.

Lewis, M. (2014) The Government has sold people out over Erudio student loans. Moneysavingexpert.com [Online], 6 May. Available at: <http://blog.moneysavingexpert.com/2014/05/06/the-government-has-sold-people-out-overerudio-student-loans/>. Accessed 27 July 2017.

Lowe, J. (2008) Value for money and the valuation of public sector assets. HM Treasury [Online], July. Available at:

<https://www.gov.uk/government/uploads/system/uploads/attachment_data/file/191488/Gree n_book_supplementary_guidance_asset_valuation.pdf>. Accessed 1 August 2017.

Lunn, E. (2014) Student loan firm Erudio under fire following government sell-off. The Guardian [Online], 20 May. Available at: <https://www.theguardian.com/money/2014/may/20/studentloan-erudio-under-fire>. Accessed 27 July 2017.

Lunn, E. (2016) Student loans firm Erudio leaves graduates fuming over latest error. The Guardian [Online], 8 April. Available at: <https://www.theguardian.com/money/2014/may/20/student-loanerudio-under-fire>. Accessed 12 September 2017.

McGettigan, A. (2013) The Great University Gamble. London: Pluto Press.

McGettigan, A. (2015) Cash today. London Review of Books [Online], 5 March. Available at: <https://www.Irb.co.uk/v37/n05/andrew-mcgettigan/cash-today>. Accessed 27 July 2017.

McGettigan, A. (2017) Critical education: Government put loan sale hopes in securitization. AndrewMcGettigan.org [Online], 6 Feb. Available at: <https://andrewmcgettigan.org/2017/02/06/governmet-put-loan-sale-hopes-in-securitisation/>. Accessed 1 Aug 2017.

Media FHE (2013) Student loan book buyer accused of mishandling accounts. Media FHE [Online]. Available at: <http://www.mediafhe.com/student-loan-book-buyer-accused-of-mishandlingaccounts >. Accessed 27 July 2017.

Mental Health Taskforce (MHT) (2016) The Five Year Forward View for Mental Health. A report from the independent Mental Health Taskforce to the NHS in England. Available at: 
<https://www.england.nhs.uk/wp-content/uploads/2016/02/Mental-Health-Taskforce-FYFVfinal.pdf $>$. Accessed 14 September 2017.

Price Waterhouse Cooper (PWC) (2017) UK Economic Outlook [Online]. Available at: <https://www.pwc.co.uk/economic-services/ukeo/pwc-uk-economic-outlook-full-report-july2017.pdf $>$. Accessed on 14 September 2017.

Richardson, T. (2017) A longitudinal study of financial difficulties and mental health in a national sample of British undergraduate students. The Community Mental Health Journal, 53(3): 344-52.

Singh, S. (2014) UK needs to tackle high cost of mental-ill health, says OECD. OECD [Online], 10 February. Available at: <http://www.oecd.org/els/emp/uk-needs-to-tackle-high-cost-of-mental-illhealth.htm>. Accessed 28 July 2017.

SLC (n.d.) Interest rates [Online]. Available at: <https://www.slc.co.uk/students-and-customers/loanrepayment/interest-rates.aspx>. Accessed 20 September 2017.

SLC and DfE (2016) Student support for Higher Education in England 2016: 2015/16 payments, 2016/17 awards. SLC [online], 30 November. Available at: <http://www.slc.co.uk/media/8444/slcsfr052016.pdf> Accessed 21 October 2017.

Sutton Trust (2015) OBR should investigate whether student loan system provides value for money. The Sutton Trust [Online], 30 July. Available at: <https://www.suttontrust.com/newsarchive/obr-shouldinvestigate-whether-student-loan-system-provides-value-for-money/>. Accessed 12 September 2017.

Timothy, N. (2017) Higher education has become unsustainable and young people know it - Radical change is the only solution. The Telegraph [Online], 17 August. Available at:

<http://www.telegraph.co.uk/news/2017/08/16/higher-education-has-become-unsustainableyoung-people-know/>. Accessed 15 September 2017.

Trendell, A. (2017) Jeremy Corbyn: 'I will deal with those already burdened with student debt'. NME [Online], 1 June. Available at: <http://www.nme.com/news/jeremy-corbyn-will-deal-alreadyburdened-student-debt-2082478\#H27wu4ygXaHWgOJ8.99>. Accessed 14 September 2017.

Woolcock, N. (2017) Ex-minister Andrew Adonis calls in watchdog over university tuition fee 'cartel'. The Times [Online], 1 July. Available at: <https://www.thetimes.co.uk/article/ex-minister-andrewadonis-calls-in-watchdog-over-university-tuition-fees-cartel-kb06k8mcx>. Accessed 17 October 2017. 